Arch. Tierz., Dummerstorf 45 (2002) 5, 501-508

Aus dem Institut für Tierzucht und Tierhaltung mit Tierklinik der Martin-Luther Universität Halle (1) und der Lohmann Tierzucht GmbH, Cuxhaven (2)

\author{
VERONICA NURGIARTININGSIH ${ }^{1}$, NORBERT MIELENZ ${ }^{1}$, RUDI PREISINGER ${ }^{2}$, \\ MATHIAS SCHMUTZ ${ }^{2}$ and LUTZ SCHÜLER ${ }^{1}$
}

\title{
Genetic parameters for egg production and egg weight of laying hens housed in single and group cages
}

\begin{abstract}
Summary
The present study was conducted to estimate the heritability and genetic correlation of monthly egg production and egg weight of 2 lines White Leghorn hens in single and group cages. A total of 2289 records (line A) and 2596 records (line D) from single cages, 518 and 541 records (for line A and D, respectively) from group cages, were analysed. (Co) variance components of single cage data were analysed using the programme VCE4 applying the REML method and a multiple trait animal model. An EM-algorithm was used to obtain (co) variance components for group cage data. Genetic correlations between single and group cages were analysed using the programme VCE4 based on sire model. Heritability estimates for monthly egg production in single cages ranged from 0.08 to 0.44 (line A); 0.04 to 0.43 (line D) and those for group cages were 0.02 to 0.42 (line A); 0.02 to 0.19 (line D). Egg weight was highly heritable for single and group cages (heritability $=0.25$ to 0.54). The genetic correlations between monthly and cumulative egg production were 0.25 to 0.95 (line A); 0.26 to 0.86 (line D) for single cage and 0.24 to 0.84 (line A); 0.26 to 0.96 (line D) for group cage. Cumulative egg production in single cage were highly correlated with those of group cages ( 0.89 and 0.63 , respectively for line A and line D). Single cage records gave higher estimates of genetic parameter than group records. However, the trend of estimates is almost the same. High genetic correlations were found between single- and group cages in most of the production periods.
\end{abstract}

Key Words: genetic parameters, egg production, egg weight, laying hens, group and single cages

\section{Zusammenfassung}

Titel der Arbeit: Genetische Parameter der Legeleistung und des Eigewichtes von Legehennen aus Gruppen- und Einzelhaltung

Die genetischen Parameter (Heritabilitäten und genetische Korrelationen) der monatlichen Legeleistung und des Eigewichtes von Legehennen zweier Linien (A, D) aus Einzel- und Gruppenhaltung werden geschätzt. 2289 (A) und 2596 Datensätze (D) aus Einzelhaltungen und 518 bzw. 541 Datensätze (Linie A bzw. D) aus Gruppenhaltung wurden in die Auswertung einbezogen. Die Daten aus der Einzelhaltung werden mit VCE-4 und REML mit einem Mehrmerkmalsmodell und die Gruppendaten mit einem EM-Algorithmus für die Varianzkomponenten ausgewertet. Die genetischen Korrelationen wurden zwischen Einzel- und Gruppenkäfigdaten mit VCE4 mittels Vatermodells geschätzt. Die Heritabilitäten für die monatliche Legeleistung aus Einzelhaltungen variierten von 0,08 bis 0,44 in Linie $A$ und von 0,04 bis 0,43 in der Linie $\mathrm{D}$ und aus Gruppenhaltung von 0,02 bis 0,42 (Linie A) bzw. 0,02 bis 0,19 (Linie D). Das Eigewicht war hoch erblich (0,25 bis 0,54 ) unter beiden Haltungsformen. Die genetischen Korrelationen zwischen monatlicher und kumulativer Legeleistung betrugen 0,25 bis 0,95 (Linien A) und 0,26 bis 0,86 in Linie D für Daten aus Einzelhaltung und entsprechend von 0,24 bis 0,84 (A) und 0,26 bis 0,06 (D) aus der Gruppenhaltung. Die kumulative Legeleistung aus Einzelhaltung war hoch korreliert mit der aus Gruppenhaltung (0,89 A, 0,63 D). Die Schätzwerte aus Einzelhaltung waren in der Tendenz höher als die aus Gruppenhaltung. Hohe genetische Korrelation wurden zwischen Leistungen aus Gruppen- und Einzelhaltung für die meisten Produktionsmonate geschätzt.

Schlüsselwörter: Genetische Parameter, Legeleistung, Eigewicht, Legehennen, Gruppenhaltung, Einzelhaltung 


\section{Introduction}

Genetic parameters of laying hens usually are estimated based on individual observations, for hens housed in single cages. However, in commercial egg production farms, hens are commonly kept in group cages. To avoid genotype and environment interactions between these different housing types, breeding hens can also be tested in group cages. Generally, data derived from group cages are available for several individuals in a group that may not be recorded for each animal but for the entire group. The recording of group performance data might be more efficient, in terms of reducing the time and cost of recording compared to recording individual observations. The magnitude of the genetic correlation between single and group observation is of fundamental importance.

Genetic parameters for monthly egg production of laying hens in single cages have been studied for several years (SAADEH et al., 1967; ENGSTROEM et al., 1986; SAVAS, 1998; ANANG et al., 2001). In addition, attempts have been done to improve annual egg production based on part records of egg production (VAN VLECK and DOOLITTLE, 1964; CRAIG et al., 1969; PREISINGER and SAVAS, 1997; AYYAGARI et al., 1983). The genetic parameters of total egg production of laying hens housed in group cages and their relations with single cages have been reported by KUEHNE (1978). The statistical method used to estimate heritabilities for group means was the application of a classical model, e.g. using hierarchical sire-dam models based on Henderson's Method 2 (KUEHNE, 1978). In animal breeding, substantial progress has been achieved in the fields of methodology and computer capacities and programmes. By using multivariate technique of analysis, it is also possible to estimate (co) variance components of single and group cages for several correlated traits simultaneously. Only few studies have been done on genetic parameter of monthly egg production of laying hens estimated based on data available in single as well as in group cages.

The present study was carried out to estimate the heritability and genetic correlation between monthly egg production and egg weight of White Leghorn tested in single and group cages.

\section{Materials and Methods}

\section{Data structure}

Egg production and egg weight data from two commercial lines of White Leghorn hens (line A: male line and line D: female line) tested in single cages as well as in group cages were used. The period of data collection was from 20 to 48 weeks of age. Egg productions was recorded in seven monthly periods, in which each period consisted of 28 days. In the group cage data, the observation unit was the average performance of hens per cage. Only cages, in which all hens survived to 7 months and hens that lay at maximum 30 eggs per period were included in the analyses. In single cage data, hens that laid more than 20 eggs within the $1^{\text {st }}$ to $7^{\text {th }}$ period and hens that survived to 7 month were included in the analyses. A total of 2289 (line A) and 2596 records (line D) in single cages, 518 and 541 records (for line A and line D, respectively) in group cage were analysed. Hens were offspring of 79 sires and 642 dams in line $\mathrm{A}$ and 80 sires and 671 dams, in line D. The traits studied were monthly 
egg production of $1^{\text {st }}$ to $7^{\text {th }}$ period (EN1 to EN7), cumulative egg production of $1^{\text {st }}$ to $7^{\text {th }}$ period (EN1-7), egg weight at 28 (EW1) and 33 (EW2) weeks of age.

\section{(Co) variance analyses}

Single cage data. (Co) variance for monthly egg productions and egg weight in single cages were analysed using VCE 4 programme (GROENEVELD, 1998) based on the restricted maximum likelihood (REML) method and a multiple trait animal model. The following model was used:

$$
\mathrm{y}_{\mathrm{ik}}=x_{i k}^{\prime} b_{k}+a_{i k}+e_{i k}
$$

where: $y_{i k}$ is record of the $i^{\text {th }}$ hen in the $k^{\text {th }}$ month; $b_{k}$ is the vector of fixed househatch-tier effect in the $\mathrm{k}^{\text {th }}$ month; $x_{i k}^{\prime}$ relates record of the $\mathrm{i}^{\text {th }}$ hen in the $\mathrm{k}^{\text {th }}$ month to vector $b_{k} ; a_{i k}$ is additive genetic effect of the $i^{\text {th }}$ hen in the $k^{\text {th }}$ month; $e_{i k}$ is random residual effect.

Group cage data. In group cages, a situation is considered, that each cage may contain a different number of hens (2, 3, or 4), in which hens within cages could be full sibs or half sibs. The following sire model was used for group cage data:

$$
\bar{y}_{i j}=x_{i j}^{\prime} b+s_{i}+\bar{r}_{i j}
$$

where: $\bar{y}_{i j}$ is the average of all animal records from the $\mathrm{j}^{\text {th }}$ cage with the $\mathrm{i}^{\text {th }}$ sire $\left(j=1,2, . ., c_{i}\right.$ where $c_{i}=$ the number of cages); $b$ is the vector of fixed effect of househatch-tier; $x_{i j}^{\prime}$ relates record of the $\mathrm{j}^{\text {th }}$ cage with the $\mathrm{i}^{\text {th }}$ sire to vector $\mathrm{b}$; $\mathrm{s}_{\mathrm{i}}$ is random effect of $i^{\text {th }}$ sire $\left(i=1, \ldots\right.$, a where a is the number of sire); $\bar{r}_{i j}$ is average of random residual effect. Because offspring of one dam could be found in different cages, the residual effects could be correlated. The components of (co) variance matrix of the residual effect vectors was described in the following formula:

$$
\begin{aligned}
& \operatorname{Var}\left(\bar{r}_{i j}\right)=\frac{\sum_{k=1}^{m_{i}} n_{i j k}^{2}}{\left(n_{i j}\right)^{2}} \sigma_{d}^{2}+\frac{\sigma_{e}^{2}}{n_{i j .}} \\
& \operatorname{Cov}\left(\bar{r}_{i j}, \bar{r}_{i j^{*}}\right)=\frac{1}{\left(n_{i j .}\right)\left(n_{i j *}\right)} \sum_{k=1}^{m_{i}} n_{i j k} n_{i j * k} \sigma_{d}^{2}
\end{aligned}
$$

where $n_{i j k}$ is number of offspring from the $\mathrm{k}^{\text {th }}$ dam in the $\mathrm{j}^{\text {th }}$ cage; $\mathrm{m}_{\mathrm{i}}$ is number of dam within the $\mathrm{i}^{\text {th }}$ vater ; $\sigma_{d}^{2}$ is variance due to dam effect; $\sigma_{e}^{2}$ is the residual variance of an individual performance in group cage. A programme based on an EM-algorithm with considering inhomogenity of error variance and correlated residual effects (MIELENZ, 2001) was used to estimate (co) variance components of group cage data.

Single and group cage data. Genetic correlations between monthly egg production in single and group cages were analysed using a sire model assuming that monthly production in single and group cages were different traits. The estimation of genetic correlations between single and group cage was enabled by the use of common sires. The programme VCE4 (GROENEVELD, 1998) was used to estimate (co) variance components of single and group cage data. 


\section{Results}

\section{Means and standard deviations}

The means of egg production in period 1 to period 7 (EN1-EN7), cumulative egg production (EN1-7) and egg weight at 28 and 33 weeks of age (EW1 and EW2) of lines A and D in single as well as group cages is displayed in Table 1. In both lines, egg production of hens in single cages tended to be higher than those in group cages. Cumulative egg production in single cages was 165.51 (line A) and 172.10 (line D) and those in group cages 162.84 and 170.25, respectively for line A and line D. From table 1 , it can be seen that line $\mathrm{D}$ had higher monthly and cumulative egg production compared to line A. This applies to single cages as well as group cages. Egg weight seems to be specific for each line, with line D producing heavier eggs than line A.

Table 1

Means and standard deviations (SD) of egg production of line A and line D in single and group cages (Mittelwerte und Standardabweichung der Legeleistung der Linien A und D in Einzel- und Gruppenhaltung)

\begin{tabular}{|c|c|c|c|c|c|c|c|c|}
\hline \multirow{3}{*}{ Traits } & \multicolumn{4}{|c|}{ Single cages } & \multicolumn{4}{|c|}{ Group cages } \\
\hline & \multicolumn{2}{|c|}{ Line A } & \multicolumn{2}{|c|}{ Line D } & \multicolumn{2}{|c|}{ Line A } & \multicolumn{2}{|c|}{ Line D } \\
\hline & Means & $\mathrm{SD}$ & Means & SD & Means & SD & Means & SD \\
\hline EN1 & 8.75 & 7.62 & 13.77 & 8.95 & 10.43 & 4.60 & 15.72 & 4.05 \\
\hline EN2 & 25.39 & 3.12 & 26.45 & 2.06 & 24.54 & 2.17 & 26.02 & 1.83 \\
\hline EN3 & 26.32 & 2.25 & 26.92 & 1.82 & 25.72 & 1.67 & 26.55 & 1.66 \\
\hline EN4 & 26.30 & 2.22 & 26.75 & 2.07 & 26.02 & 1.73 & 26.46 & 1.80 \\
\hline EN5 & 26.59 & 1.96 & 26.77 & 1.98 & 26.10 & 1.63 & 26.47 & 1.80 \\
\hline EN6 & 26.19 & 1.87 & 25.69 & 2.36 & 25.32 & 1.89 & 25.38 & 2.24 \\
\hline EN7 & 25.98 & 2.27 & 25.75 & 2.63 & 24.71 & 2.22 & 23.65 & 2.89 \\
\hline EN1-7 & 165.51 & 11.62 & 172.10 & 11.12 & 162.84 & 9.28 & 170.25 & 10.21 \\
\hline EW1 & 60.19 & 3.75 & 57.78 & 3.39 & 58.57 & 2.78 & 55.20 & 2.05 \\
\hline EW2 & 61.62 & 4.05 & 60.22 & 3.43 & 61.08 & 3.06 & 58.75 & 2.26 \\
\hline
\end{tabular}

\section{Genetic parameters}

Estimates of heritability in single and group cages are presented in Table 2.

Table 2

Heritability of monthly egg production and egg weight of line A and line D in single and group cage (Heritabilitäten für die monatliche Legeleistung der Linien A und D aus Einzel- und Gruppenhaltung)

\begin{tabular}{lcccc}
\hline Traits & \multicolumn{2}{c}{ Line A } & Single & Group \\
\cline { 2 - 5 } & Single & Group & 0.43 & 0.19 \\
\hline EN1 & 0.44 & 0.42 & 0.15 & 0.05 \\
EN2 & 0.12 & 0.23 & 0.14 & 0.02 \\
EN3 & 0.14 & 0.05 & 0.04 & 0.02 \\
EN4 & 0.09 & 0.03 & 0.05 & 0.03 \\
EN5 & 0.08 & 0.05 & 0.08 & 0.07 \\
EN6 & 0.10 & 0.02 & 0.05 & 0.11 \\
EN7 & 0.10 & 0.02 & 0.29 & 0.05 \\
EN1-7 & 0.32 & 0.18 & 0.40 & 0.25 \\
EW1 & 0.54 & 0.36 & 0.39 & 0.27 \\
EW2 & 0.44 & 0.38 & & \\
\hline
\end{tabular}

Compared to group cage data, single cage data showed higher heritability estimates for monthly egg production and egg weight, not only in line A but also in line D. The trend of heritability estimates during the 7 periods of production tended to be the same in single and group cages. Estimates were high in the $1^{\text {st }}$ period, then lower in the following periods. As expected, egg weights in both periods of measurement were 
moderately to highly heritable ranging from 0.25 to 0.54 . The total egg production in single cages showed higher heritability of 0.32 in line A than those of 0.29 in line D. In group cages, a higher estimate of heritability was also found in line A compared to line D.

The genetic correlations between monthly egg production, cumulative production and egg weight in single and group cages are presented in table 3 and table 4, for line A and line $\mathrm{D}$, respectively. It can be seen that genetic correlation of monthly egg production of each line in single as well as in group cages were high in contiguous periods and these values decreased as the interval between months increased. Most periods were negatively correlated with egg production of the $1^{\text {st }}$ period. Negative genetic correlations were found between monthly egg production and egg weight, both in single and in group cages.

Table 3

Genetic correlations of line A in single cages (above the diagonal) and group cages (below the diagonal) (Genetische Korrelationen für die Linie A aus Einzelhaltung (oberhalb der Diagonalen) und aus Gruppenhaltung (unterhalb der Diaonalen))

\begin{tabular}{rrrrrrrrrrr}
\hline Traits & EN1 & EN2 & \multicolumn{1}{c}{ EN3 } & EN4 & \multicolumn{1}{c}{ EN5 } & \multicolumn{1}{c}{ EN6 } & EN7 & EN1-7 & EW1 & EW2 \\
\hline EN1 & & 0.81 & -0.04 & -0.10 & -0.17 & -0.12 & -0.15 & 0.83 & -0.19 & -0.32 \\
EN2 & 0.45 & & 0.55 & 0.48 & 0.36 & 0.30 & 0.01 & 0.95 & -0.41 & -0.53 \\
EN3 & 0.37 & 0.95 & & 0.99 & 0.87 & 0.69 & 0.27 & 0.48 & -0.11 & -0.23 \\
EN4 & -0.06 & 0.93 & 0.94 & & 0.86 & 0.69 & 0.32 & 0.45 & -0.31 & -0.47 \\
EN5 & -0.06 & 0.66 & 0.50 & 0.87 & & 0.95 & 0.65 & 0.41 & -0.12 & -0.22 \\
EN6 & -0.08 & -0.21 & 0.17 & 0.68 & 0.69 & & 0.83 & 0.43 & -0.19 & -0.30 \\
EN7 & -0.15 & 0.02 & -0.09 & 0.63 & 0.86 & 0.95 & & 0.25 & -0.10 & -0.22 \\
EN1-7 & 0.82 & 0.84 & 0.78 & 0.64 & 0.46 & 0.25 & 0.24 & & -0.27 & -0.47 \\
EW1 & -0.53 & -0.29 & -0.40 & 0.03 & 0.09 & -0.27 & -0.05 & -0.50 & -0.95 \\
EW2 & -0.48 & -0.49 & -0.69 & -0.31 & -0.14 & -0.67 & -0.22 & -0.68 & 0.95 & 0.95 \\
\hline
\end{tabular}

Table 4

Genetic correlations of line D in single cages (above the diagonal) and group cages (below the diagonal)) (Genetische Korrelationen für die Linie D aus Einzelhaltung (oberhalb der Diagonalen) und aus Gruppenhaltung (unterhalb der Diaonalen))

\begin{tabular}{rrrrrrrrrrr}
\hline Traits & EN1 & EN2 & EN3 & EN4 & \multicolumn{1}{c}{ EN5 } & \multicolumn{1}{c}{ EN6 } & \multicolumn{1}{c}{ EN7 } & EN1-7 & EW1 & EW2 \\
\hline EN1 & & 0.08 & -0.21 & -0.19 & -0.11 & 0.02 & -0.28 & 0.86 & -0.24 & -0.23 \\
EN2 & -0.05 & & 0.86 & 0.86 & 0.72 & 0.52 & 0.39 & 0.50 & 0.03 & 0.05 \\
EN3 & -0.29 & 0.90 & & 0.86 & 0.70 & 0.42 & 0.31 & 0.26 & -0.05 & -0.09 \\
EN4 & -0.82 & 0.41 & -0.24 & & 0.82 & 0.78 & 0.73 & 0.45 & 0.01 & 0.08 \\
EN5 & -0.25 & 0.71 & 0.94 & 0.95 & & 0.84 & 0.72 & 0.47 & -0.16 & -0.18 \\
EN6 & -0.53 & 0.35 & 0.71 & 0.90 & 0.94 & & 0.92 & 0.48 & -0.16 & -0.13 \\
EN7 & -0.32 & 0.45 & 0.77 & 0.62 & 0.94 & 0.79 & & 0.21 & -0.01 & -0.04 \\
EN1-7 & 0.26 & 0.62 & 0.91 & 0.48 & 0.96 & 0.63 & 0.76 & & -0.29 & -0.25 \\
EW1 & -0.37 & -0.18 & -0.13 & -0.15 & -0.25 & -0.03 & -0.01 & -0.32 & & 0.95 \\
EW2 & -0.45 & -0.12 & -0.26 & -0.23 & -0.00 & -0.11 & -0.02 & -0.33 & 0.90 & \\
\hline
\end{tabular}

\section{Genetic correlation between monthly egg production in single and group cages}

Table 5 presents the genetic correlation between monthly egg production in single and group cages. High estimates of genetic correlations were found for $1^{\text {st }}, 2^{\text {nd }}, 3^{\text {rd }}, 4^{\text {th }}, 7^{\text {th }}$ monthly production and cumulative production, that ranged from 0.43 to 0.85 (line A) and from 0.48 to 0.95 (line D). Monthly egg production of period 5 showed extremely low estimates of genetic correlation (-0.09) in line A, but on the other hand, high values were found in line $\mathrm{D}$. 
Table 5

Genetic correlations between single and group cages for monthly and cumulative egg production (Genetische Korrelationen zwischen Daten aus Einzel- und Gruppenhaltung für monatliche und kumulative Legeleistungen)

\begin{tabular}{ccc}
\hline Traits & Line A & Line D \\
\cline { 2 - 3 } & $r_{g} \pm$ s.e & $r_{g} \pm$ s.e \\
\hline EN1 & $0.84 \pm 0.05$ & $0.84 \pm 0.07$ \\
EN2 & $0.84 \pm 0.09$ & $0.97 \pm 0.17$ \\
EN3 & $0.76 \pm 0.18$ & $0.99 \pm 0.17$ \\
EN4 & $0.77 \pm 0.38$ & $0.88 \pm 0.83$ \\
EN5 & $-0.12 \pm 0.28$ & $1.00 \pm 0.00$ \\
EN6 & $0.19 \pm 0.39$ & $0.44 \pm 0.19$ \\
EN7 & $0.39 \pm 0.42$ & $0.51 \pm 0.18$ \\
EN1-7 & $0.90 \pm 0.07$ & $0.61 \pm 0.19$ \\
EW1 & $1.0 \pm 0.00$ & $0.98 \pm 0.05$ \\
EW2 & $1.0 \pm 0.00$ & $0.94 \pm 0.05$ \\
\hline
\end{tabular}

\section{Discussion}

The trend of heritability values of monthly egg production in single cages is in basic agreement with previous studies by SAVAS (1998) and ANANG (2001). Heritability estimates of monthly egg production in group cages have not been reported. Monthly egg production of the $1^{\text {st }}$ period showed high estimates of heritability. These results agree with those of PREISINGER and SAVAS (1997) and FAIRFULL and GOWE (1990) who suggested that the high heritability for the $1^{\text {st }}$ period of laying in single cages was influenced by variation in sexual maturity. Heritability estimates for cumulative egg productions in single cages were smaller than those reported by ANANG et al. (2000), but higher than those obtained by SAVAS (1998). In group cages, heritability estimates for cumulative productions are in the same range as reported by KUEHNE (1978).

Egg weight in general has proved to be highly heritable as obtained in the present study. The results are in accordance with the findings of POGGENPOEL et al. (1996) and FRANCESCH et al. (1997) for single cages and KUEHNE (1978) for group cages. A lower heritability of $0.22-0.30$ for egg weight in White Leghorn was found by CRAIG et al. (1969). These differences may be due to the use of different methods. CRAIG et al. used a sire model. WEI and VAN DER WERF (1993) and MIELENZ et al. (1994) concluded that heritability estimates using REML method based on an animal model tend to be higher than estimates from classical models. A reason might be the completeness of the pedigrees in an animal model as compared to a sire model. Without considering the complete relationship in the model, the parameter estimation could be biased (PREISINGER and SAVAS, 1997). The heritability for egg weight seems to be different for the two lines, in which the estimates were higher in line A compared to line D. PREISINGER and SAVAS (1997) reported similar results and suggested that it may reflect the high variation in egg weight of the male line.

Compared to group cages, single cages showed higher heritability estimates for monthly egg production and egg weight in both line. KUEHNE (1978) suggested that the difference between those estimates was probably due to the reduced variability in group cages.

Monthly egg production of $1^{\text {st }}$ period in single and group cages showed negative genetic correlation with other periods. SAVAS (1998) reported similar results. In contrast, ANANG et al. (2000) reported positive correlations between first and later 
periods, which are probably due to the exclusion of hens that laid no egg in the $1^{\text {st }}$ period from the analyses. Moderate to high genetic correlation were found between monthly egg production and total production in single as well as group cages. The results for single cages were in agreement with the results of GOWE and LENTZ (1973) and SAVAS (1998), but no reports were found for group cages. It was found that genetic correlations between monthly egg production and egg weight were different for the two lines, in single as well as in group cages. The genetic correlations were higher for line A compared to those for line D. SAVAS et al. (1998) reported similar values in the range of -0.30 and -0.19 , respectively for the male line and the female line. Between successive periods of measurement of egg weight, very high estimates for genetic correlations were found.

Relatively high values were found for the genetic correlation between monthly egg production in single and group cages. KUEHNE (1978) reported a high genetic correlation (0.94) between single and group cages for cumulative egg production of $1^{\text {st }}-6^{\text {th }}$ period. In the present study, the standard error of genetic correlations ranged from 0.00 to 0.89 . The large standard error indicates that the estimates were extremely variable, possibly due to the low heritability values of the traits and the limited number of records used in the estimations.

It can be concluded that single cage records give higher estimates of heritabilities and genetic correlations in most periods compared to group cages. However, the trend of genetic parameter of monthly egg productions estimated in group cages is almost the same as those in single cages. By increasing the number of group records in the model, the precision of estimation of genetic correlation between single and group cage should be improved. In addition, advances in the methods and programme package should be very useful in order to obtain more precise and better estimates of genetic parameter of group means.

\section{Acknowledgements}

The authors wish to thank DAAD for the financial support and LOHMANN Tierzucht $\mathrm{GmbH}$ for the available data.

\section{References}

ANANG, A.:

Die Nutzung monatlicher Leistungen zur Zuchtwertschaetzung bei Legehennen. Martin-LutherUniversity, Halle-Wittenberg, PhD Thesis, 2001

ANANG, A.; SCHUELER, L.; MIELENZ, N.:

Genetic and phenotypic parameters for monthly egg production in White Leghorns. Journal Animal Breeding and Genetic, 117 (2000), 407-415

AYYAGARI, V.; MOHAPATRA, S.C.; VENKATRAMAIAH, A.; CHOUDRI, D.; THIAGASUNDARAM, T.; JOHRI, D.C.; RENGANATHAN, P..

Selelection for egg production on part records. Part 2: Correlated response to selection. Theory Applied Genetic, 64 (1983), 169 - 175

CRAIG, J.V.; BISWAS, D.K.; SAADEH, H.K.:

Genetic variation and correlated responses in chickens selected for part year rate of egg production. Poultry Science, 48 (1969), 1288-1296

ENGSTRÖM, G.; WEYDE, C.; LILJEDAHL, L.E.:

Genetic correlation and heritabilities for frequency of cracked egg number and egg weight in laying hens. British Poultry Science, 27 (1986), 55-61

FAIRFULL, R.W.; GOWE, R.S.: 
Genetics of egg production in chicken. In: Poultry Breeding and genetics. Crawford, R.D. (eds.), Elsevier. Amsterdam, pp. 705-759, 1990

FRANCESH, A.; ESTANY, J.; ALFONSO, L.; IGLESIAS, M.:

Genetic parameter for egg number, egg weight and egg shell colour in three Catalan breed. Poultry Science, 76 (1997), 1627-1631

GOWE, R.S; LENTZ, W.E.:

Long-term selection for egg production in several strains of White Leghorns: Performance of selected and control strains including genetic parameters of two control strains. Proceedings of the $4^{\text {th }}$ European Poultry Conference, London, pp. 225-245, 1973

GROENEVELD, E.:

VCE4 user's guide and reference manual version 1.1. Institut of Animal Husbandry and Animal Behaviour Federal Agricultural Research Centre Mariensee, Germany, 1998

KUEHNE, W.:

Genotyp x Umwelt-Interaktionen bei weissen Legehybriden in Einzel- bzw. Gruppenkäfighaltung. University of Georg-August, Goettingen, PhD Thesis, 1978

MIELENZ, N; GRONEVELD, E.; MUELLER, J.; SPILKE, J.:

Simultaneous estimation of variances and covariances using REML and Henderson 3 in a selected population of White Leghorns. British Poultry Science, 35 (1994), 669-676

MIELENZ, N.:

EM Algorithm with correlated residual effects (Personal communication), 2001

POGGENPOEL, D.G.; FERREIRA, G.F.; HAYES, J.P.; DU PREEZ, J.J.:

Response to long-term selection for egg production in laying hens. British Poultry Science, 37 (1996), 743-756

PREISINGER, R.; SAVAS, T.:

Vergleich zweier Methoden zur Schätzung der Varianzkomponenten für Leistungsmerkmale bei Legehenne. Züchtungkunde, 69 (1997) 2, 142-152

SAADEH, H.K.; CRAIG, J.V.; SMITH, L.T.; WEARDON, S.:

Effectiveness of alternative breeding systems for increasing rate of egg production in chickens. Poultry Science, 47 (1967), 1057-1072

SAVAS, T.:

Untersuchungen zur Verbesserung der Zuchtwertschaetzung fuer Legeleistung bei Legehennen. University of Christian-Albrechts Kiel, PhD Thesis, 1998

SAVAS, T.; PREISINGER, R.; RÖHE, R.; KALM, E.:

Genetische Parameter und optimale Prüfdauer für Legeleistung anhand von Teillegeleistungen bei Legehennen. Arch. Tierz., Dummerstorf 41 (1998), 421-432

VAN VLECK, L.D.; DOOLITTLE, D.P.:

Genetic parameters of monthly egg production in Cornell controla. Poultry Science, 43 (1964), 560 - 567

WEI, M.; VAN DER WERF, J.H.J.:

Animal model estimation of additive and dominance variances in egg production traits of poultry. In: $\mathrm{M}$. WEI. Combined crossbred and purebred selection in animal breeding. Wageningen Agricultural University, PhD Thesis, 1992

Received: 2002-06-20

Accepted: 2002-08-12

Authors' addresses

Dipl.agr. Ing. VERONICA NURGIARTININGSIH, MSc.

Dr. NORBERT MIELENZ, Prof. Dr. LUTZ SCHÜLER

Institut für Tierzucht und Tierhaltung mit Tierklinik der Martin-Luther-Universität

Halle-Wittenberg

Adam-Kuckhoff-Str. 35

D-06099 Halle

Germany

Prof. Dr. RUDI PREISINGER, Dr. MATHIAS SCHMUTZ

Lohmann Tierzucht GmbH

Am Seedeich 9-11

D 27450 Cuxhaven

Germany 